GLOBAL JOURNAL OF AGRICULTURAL SCIENCES VOL. 17, 2018: 91-107

COPYRIGHT@ BACHUDO SCIENCE CO. LTD PRINTED IN NIGERIA ISSN 1596-2903 www.globaljournalseries.com, Email: info@globaljournalseries.com

\title{
CLIMATE VARIATION, ITS IMPACT ON NON TIMBER FOREST PRODUCTS AND LIVELIHOOD OF OHAFIA PEOPLE, ABIA STATE NIGERIA
}

GERALDLINE O. IBE

(Received 22 May 2018; Revision Accepted 3 August 2018)

\begin{abstract}
Increased vulnerability of Non timber forest products to climate variation has overtime, resulted to serious negative consequences on rural dwellers that depend on rain, sunshine and wind for their fruiting, maturity and harvesting, to enhance livelihood. The scope of this study analyzed the effect of climate variability and NTFPs through peoples' perception using a field survey. The objective of the research therefore focused on the socio-economic characteristics of the respondents in the study area, activities of the people that increase the risk of climate variability, the effect of climate variability on the quantity and composition NTFPs in the study area, the perception of people on the effect of climate variability on the NTFPs and the contribution of NTFPs to their livelihood. A total of 216 respondents were sampled, the study adopted a simple random technique which was used to select 9 villages out of the 26 villages in Ohafia Local Government Area through a structured questionnaire. Findings show that large proportion $(72.2 \%)$ of the respondents censured increased temperature and heavy rainfall (64.4\%) as the most reason for decreased yield in NTFPs in the last four years. Majority $(88.9 \%$ and $58.3 \%)$ of the respondents opined that climate variability had reduced fruit yield and price instability respectively. Over $35 \%$ said climate variability had brought about species scarcity. $54.2 \%$ had no access to safe drinking water, $25.5 \%$ of the respondents made very low sales from NTFPs, while $3.2 \%$ and $29.6 \%$ faced starvation and diseases. Climate variability influence on the availability of Non timber forest products will affect the income status and food security of rural dwellers that depend on it. Vulnerabilities could be reduced through campaign on embracing climate variability plans, funding the campaign through the collaboration of government and foreign countries, re-training extension workers, cash donations and training the rural dwellers.
\end{abstract}

KEYWORDS: - Climate variability, Food security, NTFPs, Ohafia and Rural dwellers.

\section{INTRODUCTION}

Over the centuries, the benefits of Non Timber Forest Products have been significant in the lives of people particularly those of rural communities (Udeagha, 2014). Non-Timber Forest Products have continually been an important element of the forest resources completely. People are dependent upon natural resources for meeting a large number of their livelihoods. Food, fodder, firewood and medicine are important non-timber values of forests collected all year round in various locations. Apart from forest plants serving as food, it also serves as medicine.

Climate variability affects NTFPs which in turn influence its contribution to the livelihood of rural dwellers; this results to adjustment in their income and food security levels. The effect of climate variability on NTFPs has led to a decline in the food security of the rural dwellers (Udeagha, 2014). This has called for the attention of all stakeholders concerned. This has affected optimum yield of Gnetum africanum, Pentaclethra macrophylla, Tetrapleura tetraptera, Archachatina marginata etc. In Ohafia Local
Government Area, the NTFPs (such as food, fodder, medicine, fuel wood etc) are highly susceptible to ecological degradation because of high rate of poverty and the high dependence on them for livelihood (Ibe et.al.2018). Climate variability is the variation in the statistical distribution of average weather conditions over time in any region of the world (Adetayo and Owolade, 2012; Ikehi, 2014; Ikehi et al., 2014a).

NTFPs help bridge seasonal gaps in income for many farmers, and they provide a safety net for many rural households during years with low crop yields. Aigbe and Oluku 2012 stated that, forests control global climate impact, therefore they act as key agents of carbon sink in the environment. The rate at which forest resources are destroyed has at present become a global concern. NTFPs include a vast number of edible and non- edible products which are sometimes gathered from the forest by a team of urban people for subsistence or for local and external trade (Jimoh and Adebisi, 2005). Ikojo et al., 2003 viewed that of the unpredictability and varied nature of the NTFPs; a lot of households are still able to meet their 
direct needs by collecting NTFPs from the forest while some others make earnings to meet up with other needs through marketing of already harvested NTFPs.

The communities in Ohafia are experiencing extreme weather events, such as: torrential rainfall resulting in floods, erratic rainfall patterns characterized by irregular on-set and cease of rainy season, increased temperatures, decline in soil productivity resulting in low-crop yields, severe windstorms and increase in plant and animal diseases. Hence, for an intervention programme to succeed in these areas, the people, their socio-economic characteristics, the various factors affecting their livelihood have to be understood. The objectives of this research therefore focused on the socio-economic characteristics of the respondents in the study area, activities of the people that increase the risk of climate variability, the effect of climate variability on the quantity and composition NTFPs in the study area, the peoples' perception on the effect of climate variability on NTFPs and the contribution of NTFPs to their livelihood outcomes in the study.

\section{MATERIALS AND METHODS}

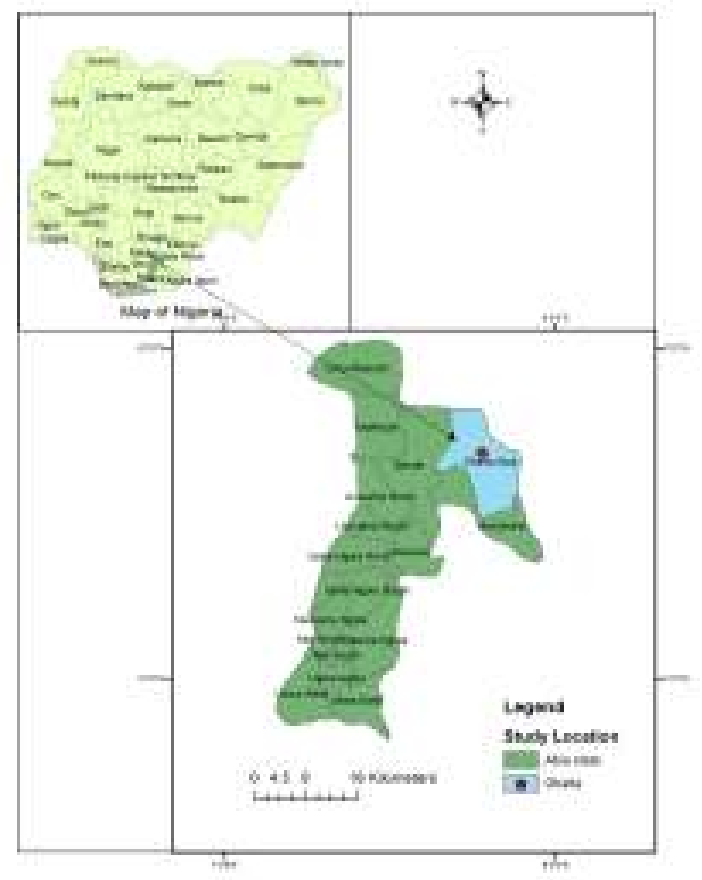

Fig 1: Map

\section{Showing location of the studied villages in Ohafia LGA, Abia State, Nigeria. \\ Data Collection, Sampling Procedure and Sample size}

Data was collected on the socio-economic characteristics, activities of the respondents, perceived impacts of climate change on the quantity and composition of NTFPs, the contribution of NTFPs to the livelihoods from 216 respondents.

The study adopted a simple random sampling technique which was used to select 9 villages out of the 26 villages

\section{Study Area}

The study was carried out in Ohafia Local Government Area of Abia State, Nigeria. Ohafia is one of the 17 local government areas in Abia State, which comprises of 26 villages. It is an Igbo speaking region and it is located in the South-eastern region of Nigeria. Ohafia is predominantly known for having a lot of NTFPs, but then, they experience series of harsh weather conditions too. Its geographical coordinates in degrees and decimal minutes are Latitude $5^{\circ} 36^{\prime \prime}$ and $5^{\circ} 48^{\prime \prime} \mathrm{N}$ and Longitude $7^{\circ} 48^{\prime \prime}$ and $7^{\circ} 52^{\prime \prime} \mathrm{E}$ and altitude of $124 \mathrm{~m}$ above sea level in the moist rainforest zone, with an average rainfall of $2177 \mathrm{~mm}$ yearly with relative humidity of about $72 \%$ and monthly ambient temperature ranges from $17^{\circ} \mathrm{C}$ to $36^{\circ} \mathrm{C}$ (Meteorological Station of NRCRI Umudike, 2004 and 2005). The vegetation is of tropical rainforest (NEST, 2011). There are two distinct seasons in a year - the rainy season which is experienced between early March and October. November to February is the dry period, and then the harmattan comes between December and January. Fig. 1 below shows where Ohafia is located in Abia State.

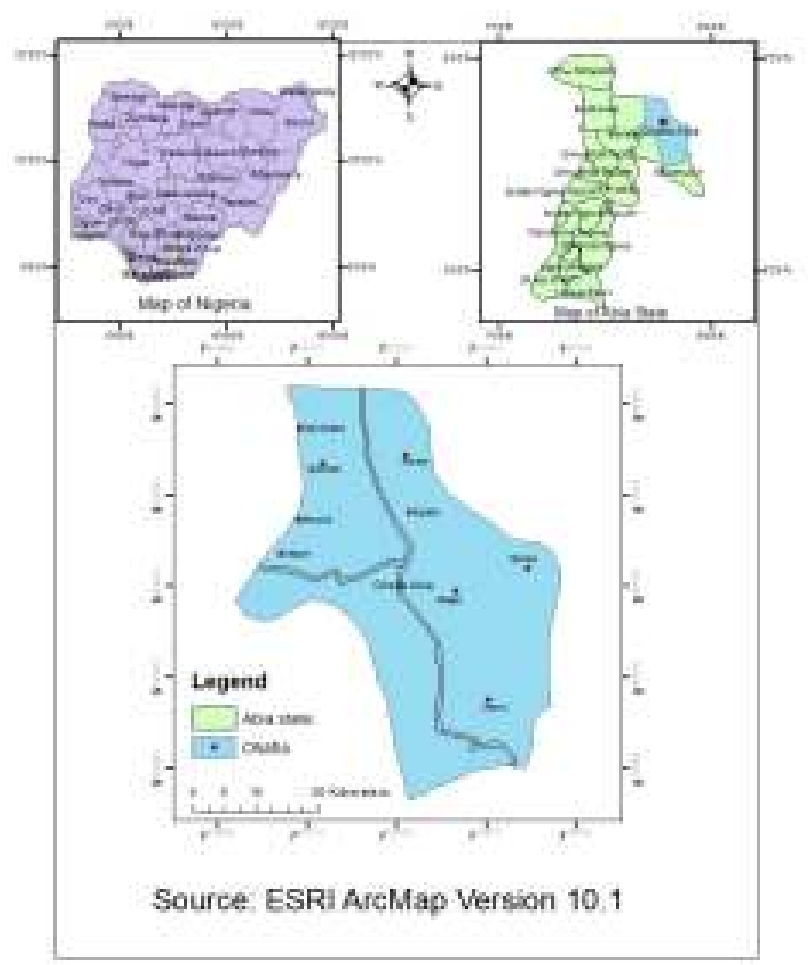

in Ohafia Local Government Area (Bernard, 2005). Systematic sampling method was then used to select every 6th house in each village, so as to attain every corner of the households. A total of 216 Household heads were interviewed. The respondents selected were $20 \%$ of the total population from each of the nine villages. (Odobode, 1999). Qualitative tools used to elicit information from the households, were participatory tools such as Focus Group Discussions (FGDs), In-depth Interviews (IDIs) with key informants (village leaders) as well as field notes and direct observations; these were 
focused on what was seen. The FGDs were two groups from each of the sampled locations made up of male groups comprised of 5 elderly and 5 youths, female groups comprised of 5 elderly and 5 youths. The IDIs comprised of 3 key informants from each village, these included (Ezeogo, Queen mother and Chief Farmer). The same questions were channeled to all the respondents.

\section{Data Analyses}

In analyzing objective 1 , which sought to examine the socio-economic characteristics of the respondents in the study area, the data collected was analyzed using both descriptive statistical methods. In analyzing objective 2, which sought to identify the activities of the respondents that contribute to climate change in the study area, means and percentages were used. To analyze objective 3 , which sought to examine the effect of climate variability on the quantity and composition NTFPs in the study area, this was analyzed using growth analysis and descriptive statistics. Thereafter, an ANOVA f-test was used to test the null hypotheses that there are no significant trends in climate variability on NTFPs in the study area. To analyze objective 4 , which sought to ascertain the contribution of NTFPs to the livelihood outcomes of the respondents in the study area, it was analyzed using regression analyses technique.

\section{RESULTS AND DISCUSSION}

\section{Socio-economic characteristics of the sampled households}

Table1 reveals that majority $(26 \%)$ of the respondents were between the age of 25- 34 years. This showed that the household heads were still in their productive working age. The implication of this is that these household heads were young, energetic and able bodied, and should therefore be able to pursue their livelihood activities with some ease and effectively such that they are able to provide for their households needs adequately. It also implies that the respondent will have a lot of experience as regard to changing climate in their environment. This agrees with the findings of Msalilwa et al. (2013), Akponikpe et al. (2010) which affirms that age have an influence in the accumulation of knowledge as regards to climate change and variability in a particular locality. Msalilwa et al., (2013) and Udeagha (2014) also affirmed that age has a positive relationship with the level of perception on climate change and variability. Majority of the household heads $(66.2 \%)$ were male, while $(33.8 \%)$ were female. Thus, it was observed that married women only gather NTFPs close or around fallow lands and farm lands while men and young ladies gather NTFPs deep in the forest areas.

Table 1: Socio-economic characteristics of sampled households

\begin{tabular}{|c|c|c|}
\hline $\mathbf{Z}$ & Frequency & Percentage \\
\hline \multicolumn{3}{|l|}{ Age of respondents } \\
\hline $18-24$ & 45 & 20.8 \\
\hline $25-34$ & 56 & 26.0 \\
\hline $35-44$ & 54 & 25.0 \\
\hline $45-54$ & 39 & 18.1 \\
\hline $55-64$ & 22 & 10.2 \\
\hline Total & 216 & 100.0 \\
\hline \multicolumn{3}{|l|}{ Marital status } \\
\hline Single & 75 & 34.7 \\
\hline Married & 121 & 56.0 \\
\hline Widowed & 19 & 8.8 \\
\hline Separated & 1 & 0.5 \\
\hline Total & 216 & 100.0 \\
\hline \multicolumn{3}{|l|}{ Gender } \\
\hline Male & 143 & 66.2 \\
\hline Female & 73 & 33.8 \\
\hline Total & 216 & 100.0 \\
\hline \multicolumn{3}{|c|}{ Educational qualification } \\
\hline None & 18 & 8.3 \\
\hline Primary & 32 & 14.8 \\
\hline JSS & 35 & 16.2 \\
\hline SSS & 95 & 44.0 \\
\hline OND/HND & 28 & 13.0 \\
\hline B.Sc & 7 & 3.2 \\
\hline $\mathrm{PhD}$ & 1 & 0.5 \\
\hline Total & 216 & 100.0 \\
\hline \multicolumn{3}{|c|}{ Household head occupation } \\
\hline Crop/livestock & 42 & 19.4 \\
\hline Crop/livestock/NTFPs & 65 & 30.1 \\
\hline Civil servant & 12 & 5.6 \\
\hline Trading in NTFPs & 18 & 8.3 \\
\hline Trading in Non NTFPs & 16 & 7.4 \\
\hline
\end{tabular}




\begin{tabular}{lll}
\hline Health worker & 7 & 3.2 \\
Hair dresser & 14 & 6.5 \\
Fishing & 3 & 1.4 \\
Hunting & 5 & 2.3 \\
Technician/Artisan & 5 & 2.3 \\
Construction worker & 7 & 3.2 \\
Wage labourer & 15 & 6.9 \\
Housewife & 7 & 3.2 \\
Total & 216 & 100.0 \\
\hline
\end{tabular}

Source: Field survey data, 2017

Table 1: cont'd on Socio-economic characteristics of sampled households

\begin{tabular}{|c|c|c|}
\hline Socioeconomic characteristics & Frequency & Percentage \\
\hline \multicolumn{3}{|l|}{ Religion } \\
\hline Christian & 195 & 90.3 \\
\hline Muslim & 2 & 0.9 \\
\hline Traditional & 19 & 8.8 \\
\hline Total & 216 & 100.0 \\
\hline \multicolumn{3}{|l|}{ Household size } \\
\hline $1-5$ & 132 & 61.1 \\
\hline $6-10$ & 66 & 30.6 \\
\hline $11-15$ & 18 & 8.3 \\
\hline Total & 216 & 100.0 \\
\hline \multicolumn{3}{|l|}{ Household type } \\
\hline Nuclear/monogamous & 162 & 75.0 \\
\hline Nuclear/polygamous & 42 & 19.4 \\
\hline Extended & 12 & 5.6 \\
\hline Total & 216 & 100.0 \\
\hline \multicolumn{3}{|l|}{ Duration of living in the community } \\
\hline Born here & 131 & 60.6 \\
\hline$<5 y$ rs & 47 & 21.8 \\
\hline $5-10 y r s$ & 19 & 8.8 \\
\hline $11-20 y r s$ & 11 & 5.1 \\
\hline$>20 y r s$ & 8 & 3.7 \\
\hline Total & 216 & 100.0 \\
\hline \multicolumn{3}{|l|}{ Own farm } \\
\hline Yes & 130 & 60.2 \\
\hline No & 86 & 39.8 \\
\hline Total & 216 & 100.0 \\
\hline \multicolumn{3}{|l|}{ How land was acquired } \\
\hline Outright Purchased & 14 & 10.8 \\
\hline Inheritance & 90 & 69.2 \\
\hline By gift & 8 & 6.2 \\
\hline By lease & 18 & 13.8 \\
\hline Total & 130 & 100.0 \\
\hline \multicolumn{3}{|l|}{ Farm size } \\
\hline Acre & 34 & 15.7 \\
\hline Hectare & 36 & 16.7 \\
\hline Plot & 142 & 65.7 \\
\hline Others & 4 & 1.9 \\
\hline Total & 216 & 100.0 \\
\hline \multicolumn{3}{|l|}{ Household main source of income } \\
\hline Crop production & 60 & 27.8 \\
\hline Livestock production & 13 & 6.0 \\
\hline Non-timber forest production/trading & 44 & 20.4 \\
\hline Full-time wage/salary & 42 & 19.4 \\
\hline Part-time wage/salary & 31 & 14.4 \\
\hline Remittance from relatives & 10 & 4.6 \\
\hline Others & 16 & 7.4 \\
\hline Total & 216 & 100.0 \\
\hline \multicolumn{3}{|c|}{ Household harvest of any NTFP in 2016} \\
\hline Yes & 166 & 76.8 \\
\hline
\end{tabular}




\begin{tabular}{lll}
\hline No & 50 & 23.2 \\
Total & 216 & 100.0 \\
\hline
\end{tabular}

Source: Field survey data, 2017.

Activities of the respondents that contribute to climate variability in the study area

Results (Table 2) showed that several land preparation was practiced by the respondents in the study area. Mould-making is the most commonly practiced land preparation mechanism before planting in the area as reported by $77.8 \%$ of the respondents. This was followed by $70.8 \%$ of the respondents that practiced ridge farming. This implies that mould and ridge making was commonly practiced by the farmers in the study area. This act of breaking up the top soil has implication for abating soil erosion and degradation. Also, $88 \%$ of the respondents are involved in burning of waste. Results also showed that large proportion $(87.5 \%)$ of the respondents carried out bush burning. This was followed by $53.2 \%$ of the respondents that used fertilizer and $46.8 \%$ of the respondents that used pesticides/herbicides. This implies that bush burning is a common practiced carried out by the people in the study area. Studies have shown that effect of climate change through bush burning practices in agriculture was a contributor to drought and desertification, which results to loss of biodiversity (Chidumayo et al., 2011). Apart from the soil destruction and desert encroachment caused by bush burning, it has also had a marked increase on the emission of Nitrate, Sulphur, Nitrous oxide, Carbon dioxide and Carbon gases which have tremendous effect in the atmosphere and also formation of acid rain which deteriorate plant life, damage calcium containing soils and also increase the acidity of surrounding lakes and rivers. (Maeda et al., 2011; Msalilwa et al., 2013 and Maeda et al, 2011). Table 2 below, majority $(52.8 \%)$ of the respondents could not say whether their daily job/ farm/ household activities have any effect on the environment while $17.1 \%$ are certain that their daily job/ farm/ household activities have an effect on the environment. This implies that there is lack of knowledge of the job/ farm/ household activities that contributes to climate variability among the people. This will affect their ability to discontinue such activities due to ignorance and thus continue to contribute to the issues that affect their environment and the climate.

Result further showed that majority $(97.3 \%)$ of those that were aware that their daily job/ farm/ household activities have effect on the environment have not done anything to reduce these activities. $97.3 \%$ posited that they don't know what to do; $94.6 \%$ of them saw it as nature's way of punishment; $86.5 \%$ of them did not feel the necessity to do anything; $89.2 \%$ of them knew what to do, but have no fund to finance it while $86.5 \%$ of the respondents see it as too big a problem for them to handle or do anything about it. This suggests that the changes in the environment under study are influenced by the activities of the people of the area without them knowing about it. Therefore, effort to control climate change in the study area cannot be successful without adequate orientation of the people on the necessity to reduce their farm and non- farm activities that affect their environment and leads to climate variability.

Table 2: Activities of the respondents that contribute to climate variability

\begin{tabular}{lll}
\hline $\begin{array}{l}\text { Anthropogenic activities of the respondents in the study } \\
\text { area }\end{array}$ & Frequency & Percentage \\
\hline *Land preparation mechanisms before planting in the area & & \\
$\begin{array}{l}\text { Shallow planting } \\
\text { Ridge making }\end{array}$ & 55 & 25.5 \\
Moulds making & 153 & 70.8 \\
$\begin{array}{l}\text { Others } \\
\text { *Common types of farm activities that are carried out in }\end{array}$ & 36 & 77.8 \\
the area & 189 & 16.7 \\
Bush burning & 101 & \\
Use of pesticides/herbicides & 115 & 87.5 \\
Use of fertilizer & 31 & 46.8 \\
Farming near water bodies & 41 & 53.2 \\
Deforestation & 36 & 14.4 \\
Slash and burn & 22 & 19.0 \\
Continuous cropping & 2 & 16.7 \\
Over grazing & 43 & 10.2 \\
Burying of fuel wood & 19 & 0.9 \\
Others & & 19.9 \\
*Means of transportation in the area & 114 & 8.8 \\
Bicycle & 129 & 52.8 \\
Motor & 83 & 59.7 \\
Cycle & 44 & 38.4 \\
Vehicle & & 20.4 \\
*Equipment use in households & & \\
Chemicals & & 19.9 \\
Insecticides & 43 & 37.0 \\
\hline
\end{tabular}




\begin{tabular}{lll}
\hline Firewood & 120 & 55.6 \\
Generator set & 77 & 35.6 \\
Energy bulb & 112 & 51.9 \\
Air fresheners & 37 & 17.1 \\
*Access to water & & \\
Streams/rivers & 172 & 79.6 \\
Underground/personal & 39 & 18.1 \\
Piped/public & 66 & 30.6 \\
Rain water harvest & 115 & 53.2 \\
Bottled water vendor & 15 & 6.9 \\
Others & 24 & 11.1 \\
*Disposal of household waste & & \\
Burning & 190 & 88.0 \\
Ground dumping & 18 & 8.3 \\
Burying & 15 & 6.9 \\
Stream disposal & 1 & 0.5 \\
Littering on the streets & 1 & 0.5 \\
Throwing into drainage/water ways & 2 & 0.9 \\
Others & 8 & 3.7 \\
Do ones' daily job/farm/ household & activities have & \\
effect on the Environment & & 17.1 \\
Yes & & 30.1 \\
No & 37 & 52.8 \\
Don't know & 65 & 100.0 \\
Total & 114 & 2.7 \\
Anything done to reduce these activities & 216 & 97.3 \\
Yes & & 100.0 \\
No & 1 & 97.3 \\
Total & 36 & 86.5 \\
*Why couldn't you do anything & 37 & 89.2 \\
Don't know what to do & & 86.5 \\
Didn't feel the necessity to do anything & 36 & 94.6 \\
Know what to do but have no money & 32 & \\
It's too big a problem & 33 & 32 \\
Its nature's way of punishment & 35 & \\
\hline$\quad$ Source: Field survey data, 2017 & & \\
\hline & & \\
\hline
\end{tabular}

Source: Field survey data, 2017

\section{* Multiple response recorded \\ Awareness of climate variability and its effect on the NTFPs in the study area}

The distribution of the respondents by their assertions of the effect of climate variability on the NTFPS in the study area (Table 3$)$. This revealed that a greater percentage $(67.6 \%)$ of the respondents have heard of climate change. From the proportion of respondents who are informed of climate change, it is obvious the chances of climate change information circulating to the people were quite high; majority got their information from the radio. Only a small proportion of the respondents $(31.9 \%)$ who were uninformed of climate change may still remain easily vulnerable to the impact of climate change. Possession of information on climate change may imply that the respondents may easily take coping or adaptive measures in the event of climate change hazards while lack of information on climate change may imply that the respondents may not be well informed on how to cope with climate change hazards. Such uninformed population may out of their ignorance, inadvertently aggravate climate change impacts. Therefore, climate variability in the study area is real but it is imperceptible to some of the rural dwellers. Given the fact that climate change is largely anthropogenic, this low commitment of the respondents to the fight to mitigate the effect of climate change level in communities of the world means that out of ignorance, people may continue to carry out those activities that accelerate climate change. From the result, it is obvious that respondents in the study area are not completely committed to mitigating climate change issues in the area and its surrounding. This may be a reflection of the lack of climate information earlier reported. The result has implications for adaptation of the impact of climate change in the study area. This finding is consistent with NEST (2011) and Umoh and Eketekpe, (2010), and it is a challenge to extension agencies. There exists a perceptible decrease in NTFPs yield in the last four years in the study area. This is expected to influence the contribution of NTFPs to the total household income of the people which will translate into poor living standard among the farmers that depends on the collection and trading of NTFPs as a means of boosting their household income. This finding supports that of Maeda et al. (2011) who predicted that climate change may affect crop yields by 2030. Therefore, NTFPs in most rural communities will continue to decrease with climate change if nothing is done rapidly to interpose the situation. 
Table 3: Awareness of climate variability

\begin{tabular}{lll}
\hline Climate Change Awareness & Frequency & Percentage \\
\hline Awareness of climate change & 146 & 67.6 \\
Yes & 69 & 31.9 \\
No & 1 & 0.5 \\
Don't know & 216 & 100.0 \\
Total & & 75.5 \\
*Source of awareness & 163 & 92.1 \\
Television & 199 & 24.5 \\
Radio & 53 & 11.1 \\
Newspaper & 24 & 19.4 \\
Internet & 42 & 12.0 \\
School & 26 & 8.8 \\
Government agents & 19 & 14.4 \\
Local council & 19.4 \\
Religious gatherings & 31 & \\
What was done with the awareness of climate change & 42 & 75.5 \\
Nothing & & 23.6 \\
Praying & 163 & 0.9 \\
Telling others & 51 & 100.0 \\
Total & 2 & 34.3 \\
Very important & 216 & 49.1 \\
Quite important & & 13.0 \\
Not very important & & 9.3 \\
Not important & 74 & 100.0
\end{tabular}

Source: Field Survey Data, 2017

* Multiple response recorded

Table 3 Climate variability effect on NTFPs

\begin{tabular}{|c|c|c|}
\hline Climate variability effect on NTFPS' Quality and Composition & Frequency & Percentage \\
\hline \multicolumn{3}{|l|}{ Feeling a decrease in NTFPs yield in the last 4 years } \\
\hline Yes & 131 & 60.6 \\
\hline No & 26 & 12.0 \\
\hline Don't know & 59 & 27.3 \\
\hline Total & 216 & 100.0 \\
\hline \multicolumn{3}{|l|}{${ }^{*}$ Reason for the decrease in NTFPs yield in the last 4 years } \\
\hline Heavy rainfall & 139 & 64.4 \\
\hline Irregular rainfall & 114 & 52.8 \\
\hline Increased temperature & 156 & 72.2 \\
\hline Increased flood frequency & 60 & 27.8 \\
\hline New insects emergence & 19 & 8.8 \\
\hline River dryness & 36 & 16.7 \\
\hline Desertification & 2 & 0.9 \\
\hline Seasonal changes & 73 & 33.8 \\
\hline Invasive species & 9 & 4.2 \\
\hline Increased land salinity & 4 & 1.9 \\
\hline Humidity pattern & 3 & 1.4 \\
\hline Others & 13 & 6.0 \\
\hline \multicolumn{3}{|l|}{ Effect of climate variability on NTFPs } \\
\hline Reduced fruit yield & 192 & 88.9 \\
\hline Price instability & 126 & 58.3 \\
\hline Loss of farmland & 87 & 40.3 \\
\hline Reduced fodder & 39 & 18.1 \\
\hline Reduced roots and herbs & 30 & 13.9 \\
\hline Causes scarcity of species & 76 & 35.2 \\
\hline Lower the productivity of medicinal plants & 29 & 13.4 \\
\hline Shading of leafs and immature flowers/fruits of NTFPs & 73 & 33.8 \\
\hline \multicolumn{3}{|l|}{ Effect of climate variability on livelihood of the people } \\
\hline Inaccessibility to safe drinking water & 117 & 54.2 \\
\hline
\end{tabular}




\begin{tabular}{|c|c|c|}
\hline Lack of capital & 113 & 52.3 \\
\hline High cost of transportation & 96 & 44.4 \\
\hline Low sales from NTFPs & 55 & 25.5 \\
\hline Bad roads & 86 & 39.8 \\
\hline Waste disposal on pathways & 17 & 7.9 \\
\hline Lack of electricity due to excessive wind that damages poles & 34 & 15.7 \\
\hline $\begin{array}{l}\text { Starvation due to lack of food especially from NTFPS } \\
\text { *Indicators of climate change in the area }\end{array}$ & 7 & 3.2 \\
\hline Temperature variability & 178 & 82.4 \\
\hline Precipitation & 66 & 30.6 \\
\hline Unusual natural/seasonal changes & 127 & 58.8 \\
\hline Flooding & 65 & 30.1 \\
\hline Irregular rainfall pattern & 90 & 41.7 \\
\hline Breakdown in NTFPs yield & 52 & 24.1 \\
\hline Desertification & 12 & 5.6 \\
\hline River dryness & 22 & 10.2 \\
\hline New insects emerged & 14 & 6.5 \\
\hline Invasive species/prying plants & 14 & 6.5 \\
\hline Humidity pattern & 4 & 1.9 \\
\hline Others & 18 & 8.3 \\
\hline
\end{tabular}

Source: Field Survey Data, 2017

\section{* Multiple response recorded \\ Quantity of harvested NTFPs in the last four years in the study area}

Results (Table 4) showed that the quantity harvested of Pentaclethra macrophylla -Ugbaga (Oil Beans) by the households in the study area declined significantly $(\mathrm{P}<$ 0.05 ) from an average of $8.15^{\mathrm{a}}$ in 2013 to $5.07^{\mathrm{d}}$ in 2016. An average growth rate of only $17 \%$ was recorded. There was significant difference at $\mathrm{P}<0.05$ in the quantity of Pentaclethra macrophylla - Ugbaga (Oil Beans) harvested by households in the last four years in the study area. Similarly, the quantity harvested of Xylopia aethiopicum Uda (Guinea Pepper) by the households in the study area declined significantly $(P<0.05)$ from an average of $9.72^{a}$ in 2013 to $7.33^{\mathrm{d}}$ in 2016 . An average growth rate of only $10 \%$ was recorded in the quantity of Xylopia aethiopicum Uda (Guinea Pepper) harvested by households in the study area between 2013 and 2016. There were significant differences at $\mathrm{P}<0.05$ among the harvested NTFPs over the four years. These findings imply that there is a decrease in the quantity of NTFPs harvested by the household in the study area in the last four years. This will negatively affect the livelihood of the people in the study area, since most of these rural people depend on NTFPs as a source of generating income to support their standard of living. This finding is consistent with Udeagha (2014) who noted a decrease in NTFPs harvested by sampled households in Cross River State, Nigeria.

Table 4: Variation in the average quantity harvested of NTFPs by households in the study area in the last four years in $\mathrm{kg}$.

\begin{tabular}{|c|c|c|c|c|c|c|c|}
\hline NTFPs & $\begin{array}{l}\text { Unit of } \\
\text { measurements weighed in kg/ton }\end{array}$ & 2013 & 2014 & 2015 & 2016 & $\begin{array}{l}\text { Anova } \mathrm{F} \\
\text { probability }\end{array}$ & $\begin{array}{l}\text { Growth } \\
(\%)\end{array}$ \\
\hline Ugbaga(Oil Beans) & Bucket & $8.15^{\mathrm{a}}$ & $7.11^{\mathrm{b}}$ & $6.06^{c}$ & $5.07^{d}$ & 0.000 & 17 \\
\hline Uda(Guinea Pepper) & Cup/kg & $9.72^{\mathrm{a}}$ & $8.84^{b}$ & $7.95^{\mathrm{c}}$ & $7.33^{d}$ & 0.002 & 10 \\
\hline Ukazi (Gnetum) & Bundles & $10.98^{a}$ & $9.97^{\mathrm{b}}$ & $8.97^{\mathrm{c}}$ & $8.43^{d}$ & 0.001 & 9 \\
\hline Ochiogochio (Tetraptera) & Basins & $6.67^{\mathrm{a}}$ & $5.67^{\mathrm{b}}$ & $4.69^{c}$ & $3.52^{d}$ & 0.005 & 24 \\
\hline Ikolo (Snail) & Basins & $8.41^{\mathrm{a}}$ & $7.71^{\mathrm{b}}$ & $6.46^{\mathrm{c}}$ & $5.44^{d}$ & 0.008 & 16 \\
\hline Nmanu anu (honey) & Bottles & $7.81^{a}$ & $7.01^{b}$ & $5.90^{\mathrm{c}}$ & $5.23^{d}$ & 0.000 & 14 \\
\hline Mmimmi (Pepper fruit) & Cup & $8.03^{a}$ & $7.73^{b}$ & $7.73^{\mathrm{c}}$ & $7.14^{d}$ & 0.009 & 4 \\
\hline Mgborogwu (roots) & Bottles & $9.45^{\mathrm{a}}$ & $9.15^{b}$ & $7.31^{\mathrm{c}}$ & $6.45^{d}$ & 0.000 & 14 \\
\hline Anuofia (Bushmeat) & None & $6.71^{\mathrm{a}}$ & $5.21^{\mathrm{b}}$ & $4.09^{c}$ & $3.02^{d}$ & 0.002 & 31 \\
\hline Osu, Erue (mushrooms) & Basins & $6.62^{\mathrm{a}}$ & $4.62^{b}$ & $4.33^{\mathrm{c}}$ & $3.66^{d}$ & 0.000 & 23 \\
\hline
\end{tabular}


Source: Field Survey Data, 2017 Value in each row followed by different superscripts is statistically different at $(P<0.05)$. Mean separation was done using Duncan Multiple Range Test.

Quantity of sold NTFPs in the last four years in the study area

Result (Table 5) showed that the quantity sold of Pentaclethra macrophylla - Ugbaga (Oil Beans) by the households in the study area declined significantly $(P<$ 0.05 ) from an average of $6.68^{\mathrm{a}}$ in 2013 to $3.90^{\mathrm{d}}$ in 2016 . An average growth rate of only $20 \%$ was recorded in the quantity of Pentaclethra macrophylla - Ugbaga (Oil Beans) sold by households in the study area between 2013 and 2016. There was significant difference at $P<0.05$ in the quantity of Pentaclethra macrophylla - Ugbaga (Oil Beans) sold by households in the last four years in the study area. There were significant differences at $P<0.05$ among the sold NTFPs over the four years. An average growth rate of only $22 \%$ was recorded in the quantity of Agaricus bisporus - Osu, Erue (mushrooms) sold by households in the study area between 2013 and 2016. There was significant difference at $\mathrm{P}<0.05$ in the quantity of Agaricus bisporus - Osu, Erue (mushrooms) sold by households in the last four years in the study area. These findings imply that there was a decrease in the quantity of NTFPs sold by the household in the study area in the last four years. This will negatively affect the livelihood of the people in the study area since most of these rural people depend on NTFPs as a source of generating income to support their standard of living.

Table 5: Variation in the average quantity sold of NTFPs by households in the study area in the last four years in $\mathbf{k g}$.

\begin{tabular}{|c|c|c|c|c|c|c|c|}
\hline NTFPs & $\begin{array}{l}\text { Unit of } \\
\text { Measurement weighed in } \mathrm{kg}\end{array}$ & 2013 & 2014 & 2015 & 2016 & $\begin{array}{l}\text { Anova } \\
\text { probability }\end{array}$ & $\begin{array}{l}\text { Growth } \\
(\%)\end{array}$ \\
\hline Ugbaga(Oil Beans) & Bucket & $6.68^{a}$ & $6.39^{b}$ & $4.66^{\mathrm{c}}$ & $3.90^{\mathrm{d}}$ & 0.004 & 20 \\
\hline Uda(Guinea Pepper) & Cup & $8.85^{\mathrm{a}}$ & $6.89^{b}$ & $6.64^{\mathrm{c}}$ & $6.12^{\mathrm{d}}$ & 0.005 & 14 \\
\hline Ukazi (Gnetum) & Bundles & $8.35^{\mathrm{a}}$ & $7.38^{\mathrm{b}}$ & $7.85^{\mathrm{c}}$ & $7.38^{\mathrm{d}}$ & 0.001 & 5 \\
\hline Ochiogochio (Tetraptera) & Basins & $5.47^{\mathrm{a}}$ & $4.42^{b}$ & $4.20^{\mathrm{C}}$ & $3.15^{\mathrm{d}}$ & 0.001 & 21 \\
\hline Ikolo (Snail) & Basins & $6.64^{\mathrm{a}}$ & $5.55^{\mathrm{b}}$ & $5.21^{\mathrm{c}}$ & $4.39^{\mathrm{d}}$ & 0.002 & 15 \\
\hline Nmanu anu (honey) & Bottles & $6.09^{a}$ & $5.68^{b}$ & $4.83^{\mathrm{c}}$ & $4.28^{\mathrm{d}}$ & 0.005 & 13 \\
\hline Mmimmi (Pepper fruit) & Cup & $6.42^{\mathrm{a}}$ & $6.05^{\mathrm{b}}$ & $7.05^{\mathrm{c}}$ & $5.51^{\mathrm{d}}$ & 0.000 & 16 \\
\hline Mgborogwu (roots) & Bottles & $7.29^{a}$ & $6.14^{\mathrm{b}}$ & $6.10^{c}$ & $5.38^{d}$ & 0.003 & 11 \\
\hline Anuofia (Bushmeat) & None & $4.63^{\mathrm{a}}$ & $3.33^{\mathrm{b}}$ & $3.48^{\mathrm{c}}$ & $2.15^{\mathrm{d}}$ & 0.001 & 32 \\
\hline Osu, Erue (mushrooms) & Basins & $5.49^{\mathrm{a}}$ & $3.97^{\mathrm{b}}$ & $3.98^{\mathrm{c}}$ & $3.08^{d}$ & 0.001 & 22 \\
\hline
\end{tabular}

Source: Field Survey Data, 2017 Value in each row followed by different superscripts is statistically different at $(P<0.05)$. Mean separation was done using Duncan Multiple Range Test. 
Variations in the average price of NTFPs in the last four years in the study area

Table 6 shows the variation in the average price of NTFPs in the market in the study area in the last four years. The result showed that for all the NTFPs considered in the study, there was significant increase in their average price between 2013 and 2016. The growth rate in their average prices were negative, which suggests that the average prices of these NTFPs increases overtime. The increase in the prices of Pentaclethra macrophylla - Ugbaga (Oil Beans); Xylopia aethiopicum - Uda (Guinea Pepper); Gnetum africanum - Ukazi; Tetrapleura tetraptera Ochiogochio; Archachatina marginata - Ikolo (Snail); Apis mellifera - Nmanu anu (Honey); Dennetia tripetala Mmimmi (Pepper fruit); Mgborogwu (Roots); Anuofia (Bushmeat) and Agaricus bisporus - Osu/Erue (Mushrooms) in the studied area, suggests that there is scarcity in the supply, this means a decline in the availability of the NTFPs overtime and thus, allows for the invisible hands of demand and supply to influence the unit prices of these NTFPs produces in the studied area. The higher price for the 2016 season than in the 2013 season is an indication of decreased supply of the product thus creating a demand gap which pushed the price upward. The NTFPs were relatively low in abundance in the 2016 season than in the 2013 season and this affected the supply of the product these seasons. The villagers were also in the position to actually bargain for the selling price of the product unlike when it very abundance, the broker normally take advantage of it and offer low price. That is when NTFPs products are in abundance the brokers become price makers vice versa. They villagers become price taker since they will be in the position to determine the market price at that particular season.

Table 6: Variation in the average price of NTFPs in the study area in the last four years in kg.

\begin{tabular}{|c|c|c|c|c|c|c|c|}
\hline NTFPs & $\begin{array}{l}\text { Unit of } \\
\text { measurement } \\
\text { weighed in } \\
\mathrm{kg}\end{array}$ & 2013 & 2014 & 2015 & 2016 & $\begin{array}{l}\text { Anova F } \\
\text { probability }\end{array}$ & $\begin{array}{l}\text { Growth } \\
(\%)\end{array}$ \\
\hline Ugbaga(Oil Beans) & Bucket & $1573.83^{\mathrm{d}}$ & $1674.28^{\mathrm{C}}$ & $1839.87^{b}$ & $1989.05^{\mathrm{a}}$ & 0.002 & -7 \\
\hline Uda(Guinea Pepper) & Cup & $38.13^{\mathrm{d}}$ & $41.41^{\mathrm{c}}$ & $45.50^{\mathrm{b}}$ & $50.00^{\mathrm{a}}$ & 0.000 & -9 \\
\hline Ukazi (Gnetum) & Bundles & $378.42^{d}$ & $415.85^{c}$ & $456.97^{b}$ & $502.17^{\mathrm{a}}$ & 0.004 & -9 \\
\hline $\begin{array}{l}\text { Ochiogochio } \\
\text { (Tetraptera) }\end{array}$ & Basins & $79.19^{d}$ & $86.45^{\mathrm{C}}$ & $95.00^{\mathrm{b}}$ & $100.00^{\mathrm{a}}$ & 0.001 & -7 \\
\hline Ikolo (Snail) & Basins & $473.56^{d}$ & $498.48^{C}$ & $547.78^{\mathrm{b}}$ & $601.96^{a}$ & 0.000 & -8 \\
\hline Nmanu anu (honey) & Bottles & $747.88^{d}$ & $803.31^{c}$ & $882.75^{\mathrm{b}}$ & $1003.13^{\mathrm{a}}$ & 0.000 & -9 \\
\hline Mmimmi (Pepper fruit) & Cup & $45.34^{d}$ & $47.72^{\mathrm{c}}$ & $52.44^{\mathrm{b}}$ & $57.63^{\mathrm{a}}$ & 0.002 & -8 \\
\hline Mgborogwu (roots) & Bottles & $1536.80^{d}$ & $1684.91^{c}$ & $1851.55^{\mathrm{b}}$ & $1990.91^{a}$ & 0.003 & -8 \\
\hline Anuofia (Bushmeat) & None & $4861.56^{d}$ & $5171.88^{c}$ & $5683.38^{b}$ & $6046.15^{a}$ & 0.002 & -7 \\
\hline Erue & asins & $448.88^{d}$ & $504.36^{c}$ & $554.25^{\mathrm{b}}$ & $577.34^{a}$ & 0.001 & -8 \\
\hline
\end{tabular}

(mushrooms)

Source: Field Survey Data, 2017 Value in each row followed by different superscripts is statistically different at $(P<0.05)$. Mean separation was done using Duncan Multiple Range Test

Trend in the revenue from the sales of NTFPs in the last four years in the study area

Result (Table 7) showed that for all the NTFPs considered in the study, there was significant decrease in revenue accruing to the collectors between 2013 and 2016. The growth rates in their average prices were negative, suggesting that the revenue from the sales of NTFPs decreases overtime. The Duncan multiple range tests show that there was significant difference $(P<0.05)$ in the revenue accruing to NTFPs collectors between

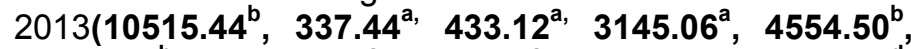
$\left.11196.32^{\mathrm{b}}, 22507.40^{\mathrm{a}}, 2465.66^{\mathrm{a}}\right)$ and $2016\left(7757.30^{\mathrm{d}}\right.$, $306.00^{b}, 315.00^{d}, 2642.60^{d}, 4293.40^{c}, 10711.10^{c}$ $, 12999.22^{\mathrm{d}}, 1778.21^{\mathrm{d}}$ ) seasons respectively. The revenue that accrued to the respondents in the 2013 was significantly higher $(P<0.05)$ than the 2016 season. The higher revenue for the 2013 season is an indication of increased supply of the product. People with little economic elasticity are likely being at the risk of increased poverty since their dependence on NTFPs is going to reduce, due to low availability of the product recently. These may still continue into the future if adequate measure and policies to livelihood are not put in place to increase their resilience to adapt to this shortfall in supply of NTFPs in the studied area. The higher revenue for the 2013 season is an indication of increased supply of the product. People with little economic elasticity are likely be at the risk increased poverty since their dependence on NTFPs is going to reduce, due to low availability of the product recently. As these may still continue into the future if adequate measure, policies and surrogate to livelihood are not put in place to increase their resilience to adapt to this shortfall in supply of NTFPs in the studied area. This result is consistent with the finding of Heubes et al. (2012) and Heubach (2011) predicted a negative impact on the economic return from NTFPs due to impact of climate and land use changes in West Africa. These environmental changes will strongly affect the provisioning ecosystem service of NTFPs (Heubes et al ., 2012 , Heubes et al ., 2013). 
Table 7: Trend in the revenue from the sales of NTFPs by households in the study area in the last four years in kg.

\begin{tabular}{|c|c|c|c|c|c|c|c|}
\hline NTFPs & $\begin{array}{l}\text { Unit of } \\
\text { measurement } \\
\text { weighed in } \\
\mathrm{kg}\end{array}$ & 2013 & 2014 & 2015 & 2016 & $\begin{array}{l}\text { Anova } \mathrm{F} \\
\text { probability }\end{array}$ & $\begin{array}{l}\text { Growth } \\
(\%)\end{array}$ \\
\hline Ugbaga(Oil Beans) & Bucket & $10515.44^{b}$ & $10706.37^{\mathrm{a}}$ & $8579.62^{C}$ & $7757.30^{d}$ & 0.002 & -11 \\
\hline Uda(Guinea Pepper) & Cup & $337.44^{\mathrm{a}}$ & $285.37^{d}$ & $301.94^{c}$ & $306.00^{b}$ & 0.001 & -4 \\
\hline Ukazi (Gnetum) & Bundles & $3158.24^{c}$ & $3069.38^{d}$ & $3587.45^{\mathrm{b}}$ & $3706.01^{a}$ & 0.001 & -5 \\
\hline $\begin{array}{l}\text { Ochiogochio } \\
\text { (Tetraptera) }\end{array}$ & Basins & $433.12^{a}$ & $382.35^{c}$ & $399.00^{b}$ & $315.00^{d}$ & 0.000 & -12 \\
\hline Ikolo (Snail) & Basins & $3145.06^{a}$ & $2766.01^{\mathrm{c}}$ & $2854.14^{\mathrm{b}}$ & $2642.60^{d}$ & 0.000 & -6 \\
\hline Nmanu anu (honey) & Bottles & $4554.50^{\mathrm{b}}$ & $4559.66^{a}$ & $4265.78^{d}$ & $4293.40^{\mathrm{C}}$ & 0.002 & -2 \\
\hline $\begin{array}{l}\text { Mmimmi } \\
\text { fruit) }\end{array}$ & Cup & $290.92^{c}$ & $288.89^{d}$ & $369.67^{\mathrm{b}}$ & $375.17^{\mathrm{a}}$ & 0.004 & -8 \\
\hline Mgborogwu (roots) & Bottles & $11196.32^{b}$ & $10344.02^{d}$ & $11285.42^{\mathrm{a}}$ & $10711.10^{c}$ & 0.000 & -2 \\
\hline Anuofia (Bushmeat) & None & $22507.40^{\mathrm{a}}$ & $17243.97^{c}$ & $19806.41^{b}$ & $12999.22^{d}$ & 0.000 & -23 \\
\hline $\begin{array}{ll}\begin{array}{l}\text { Osu, } \\
\text { (mushrooms) }\end{array} & \text { Erue } \\
\end{array}$ & Basins & $2465.66^{a}$ & $2003.03^{c}$ & $2205.35^{\mathrm{b}}$ & $1778.21^{d}$ & 0.001 & -13 \\
\hline
\end{tabular}

Source: Field Survey Data, 2017 Value in each row followed by different superscripts is statistically different at $(P$ $<0.05)$. Mean separation was done using Duncan Multiple Range Test.

The percentage of the responses on the level of availability of NTFPs in the last four years is shown in the Figs.2 to 4. The figures show that Ugbaga (Oil Beans), Uda (Guinea Pepper), Ukazi (Gnetum spp.), Ochiogochio (Tetraptera spp.), Ikolo (Snail), Nmanu anu (Honey),
Mmimmi (Pepper fruit), Mgborogwu (Roots), Anuofia (Bushmeat) and Osuerue (Mushrooms)were in abundance in 2013 and 2014 in the studied area, but, were found to be declining in the year 2015 and 2016.
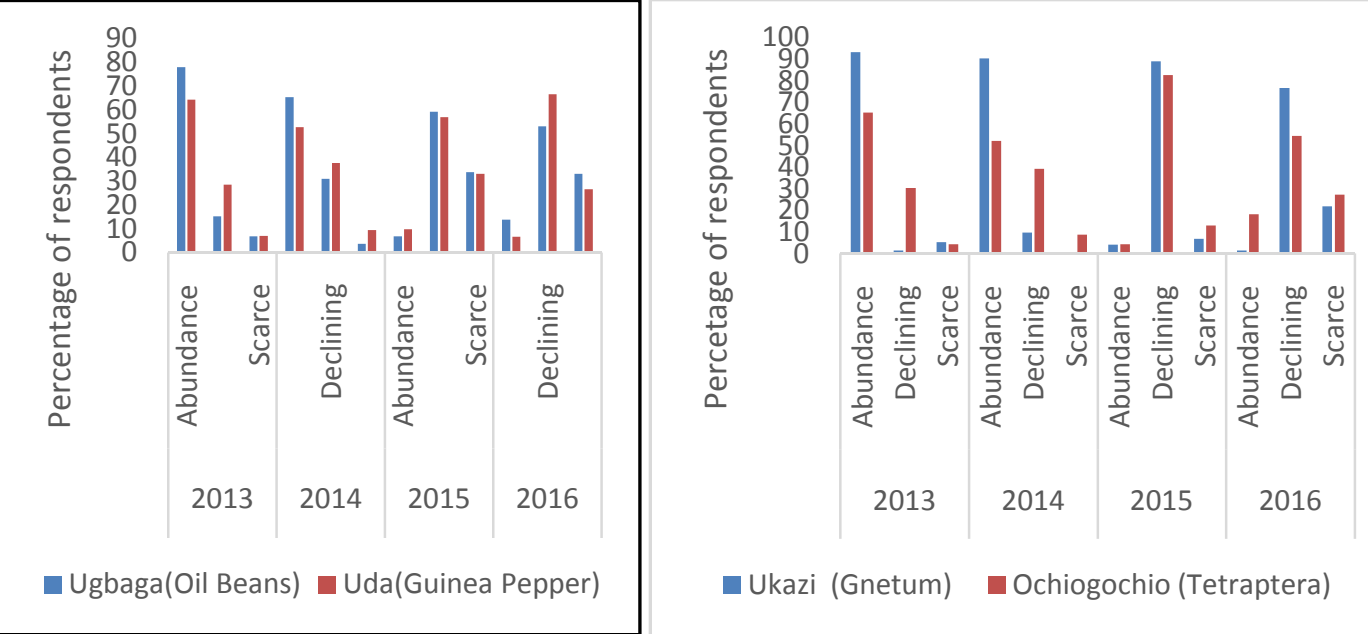

Fig: 2: Variation in the availability of Ugbaga(Oil beans), Uda(Guinea pepper), Ukazi (Gnetum), and Ochiogochio (Tetraptera)in the study area in the last four years. 

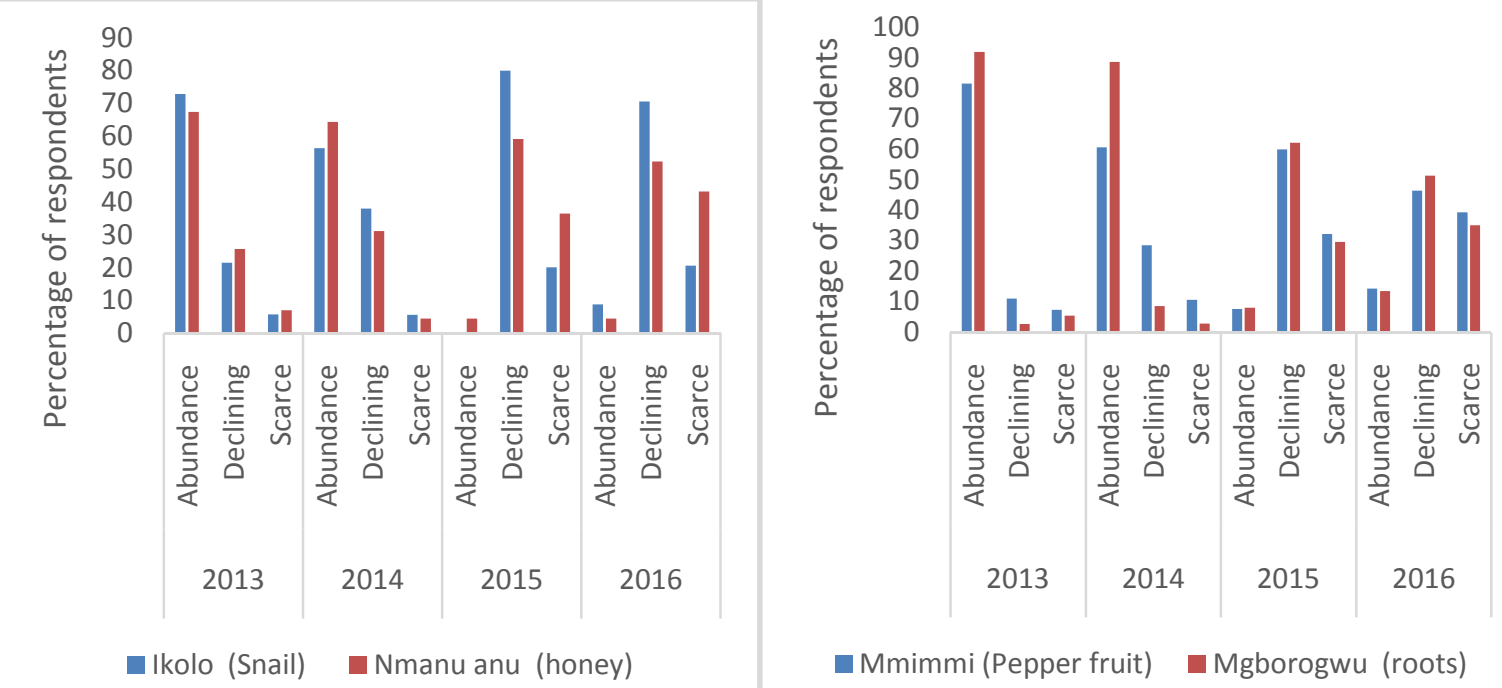

Fig: 3: Variation in the availability of Ikolo(Snail), Nmanu anu(Honey), Mmimmi (Pepper fruit) and Mgborogwu (Herbs) in the study area in the last four years.

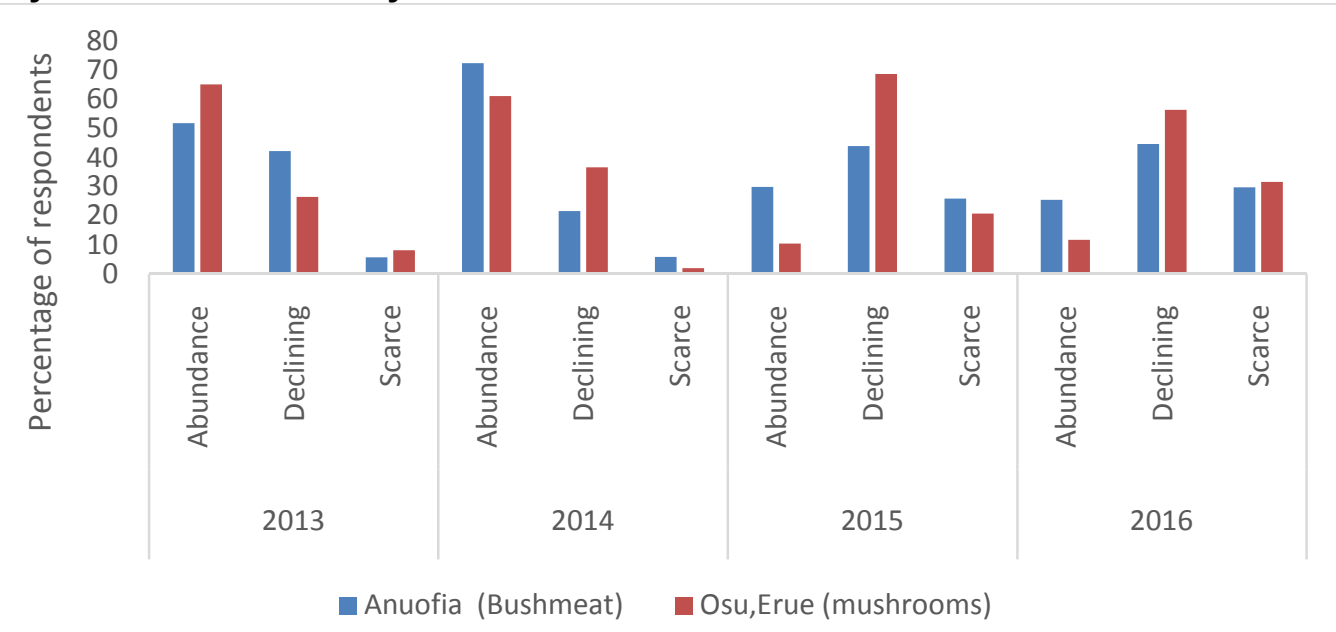

Fig: 4: Variation in the availability of Anuofia (bush meat)and Osu-erue (mushroom) in the study area in the last four years.

Perception of the respondents on the observed weather change in the study area in the last 4 years.

From the respondents (Table 8), there were high invasive species $(42.0 \%$ and $43.5 \%)$ emerged in 2013 and 2014. The rainfall pattern was predominantly high $(47.9 \%)$ in 2013 but relatively low (45.3\%) in 2015. Deforestation has been excessively practiced throughout the 4 years. Changes in the amount of rain, increased intensity, and changes in rainfall patterns would weaken the root system of trees and increase the rate of wind- throw in forests, destruction and die off of many tree species that are intolerant to water logging (NEST, 2011, Abiodun et al.,
2013). This will contribute to overall decline in forest cover and herbaceous understory productivity, thus affecting forest products, including NTFPs for human consumption and use. In 2015 and 2016, large proportions of the respondents reputed that the observed flooding frequency was moderate and high respectively. This implies that probably there was an increase in the frequency of flooding. Increased flooding can be expected following periods of intense rain in areas with poor infiltration rates, potentially causing water logging and decline in nonadapted forest (NEST, 2011; Abiodun et al., 2013). 
Table 8: Perception of the respondents on the observed weather change in the study area in the last 4 years.

\begin{tabular}{|c|c|c|c|c|c|c|c|c|c|c|c|c|}
\hline \multirow{2}{*}{$\begin{array}{l}\text { Observed } \\
\text { weather change }\end{array}$} & \multicolumn{3}{|c|}{2013} & \multicolumn{3}{|c|}{2014} & \multicolumn{3}{|c|}{2015} & \multicolumn{3}{|c|}{2016} \\
\hline & 동 & $\begin{array}{l}\underline{\Sigma} \\
\bar{D} \\
\overline{0} \\
\Sigma\end{array}$ & ב⿱ & 家 & $\begin{array}{l}\frac{E}{J} \\
\frac{\bar{D}}{0} \\
\Sigma \\
\Sigma\end{array}$ & ב⿱ & 家 & $\begin{array}{l}\underline{\Sigma} \\
\frac{D}{\partial} \\
\Sigma \\
\Sigma\end{array}$ & ב & 호 & $\begin{array}{l}\frac{E}{3} \\
\frac{\bar{D}}{0} \\
\sum\end{array}$ & ב⿱ \\
\hline $\begin{array}{ll}\text { Invasive } & \text { species } \\
\text { emerged } & \end{array}$ & 42.0 & 33.7 & 24.3 & 43.5 & 44.0 & 12.5 & 22.7 & 55.2 & 22.1 & 18.8 & 35.9 & 45.3 \\
\hline Rainfall pattern & 47.9 & 40.1 & 12.0 & 14.1 & 39.6 & 46.4 & 10.9 & 43.8 & 45.3 & 53.3 & 37.1 & 9.6 \\
\hline Temperature & 26.5 & 49.2 & 24.3 & 46.8 & 30.6 & 22.6 & 16.0 & 34.0 & 50.0 & 51.8 & 33.8 & 14.4 \\
\hline Flood frequency & 36.6 & 40.6 & 22.9 & 41.2 & 37.8 & 21.1 & 36.9 & 39.4 & 23.8 & 40.7 & 30.2 & 29.1 \\
\hline $\begin{array}{l}\text { River erosion/dry } \\
\text { up }\end{array}$ & 63.5 & 4.7 & 31.7 & 66.3 & 8.1 & 25.6 & 59.0 & 9.9 & 31.2 & 65.6 & 27.0 & 7.4 \\
\hline Deforestation & 79.2 & 3.9 & 16.9 & 84.2 & 5.0 & 10.8 & 82.8 & 10.0 & 7.2 & 87.1 & 1.3 & 11.6 \\
\hline $\begin{array}{l}\text { Seasonal } \\
\text { changes/wind } \\
\text { force }\end{array}$ & 66.8 & 5.5 & 27.7 & 57.2 & 9.5 & 33.3 & 50.4 & 29.3 & 20.3 & 67.2 & 28.6 & 4.2 \\
\hline Land salinity & 48.7 & 13.3 & 38.1 & 56.6 & 23.0 & 20.4 & 57.0 & 28.1 & 14.9 & 56.9 & 23.4 & 19.7 \\
\hline Sunshine intensity & 58.2 & 30.1 & 11.7 & 30.3 & 3.2 & 66.5 & 50.3 & 36.2 & 13.5 & 70.6 & 25.7 & 3.7 \\
\hline Humidity pattern & 46.3 & 37.2 & 16.5 & 52.8 & 32.3 & 14.9 & 28.6 & 15.5 & 55.9 & 42.8 & 46.8 & 10.4 \\
\hline Wind force & 49.3 & 26.2 & 24.5 & 30.4 & 49.5 & 20.1 & 14.0 & 40.0 & 46.0 & 61.6 & 29.3 & 9.1 \\
\hline
\end{tabular}

\section{Source: Field Survey Data, 2017}

The diagrammatic presentation of the collected four years monthly data on rainfall, temperature, relative humidity, sunshine and wind force from the meteorological centre National Root Crops Research Institute (N.R.C.R.I)
Umudike Abia state, Nigeria which is the verification of the certitude in the observations of the respondents on climate change is shown in Figs. 5 to 9 below counting from left to right.
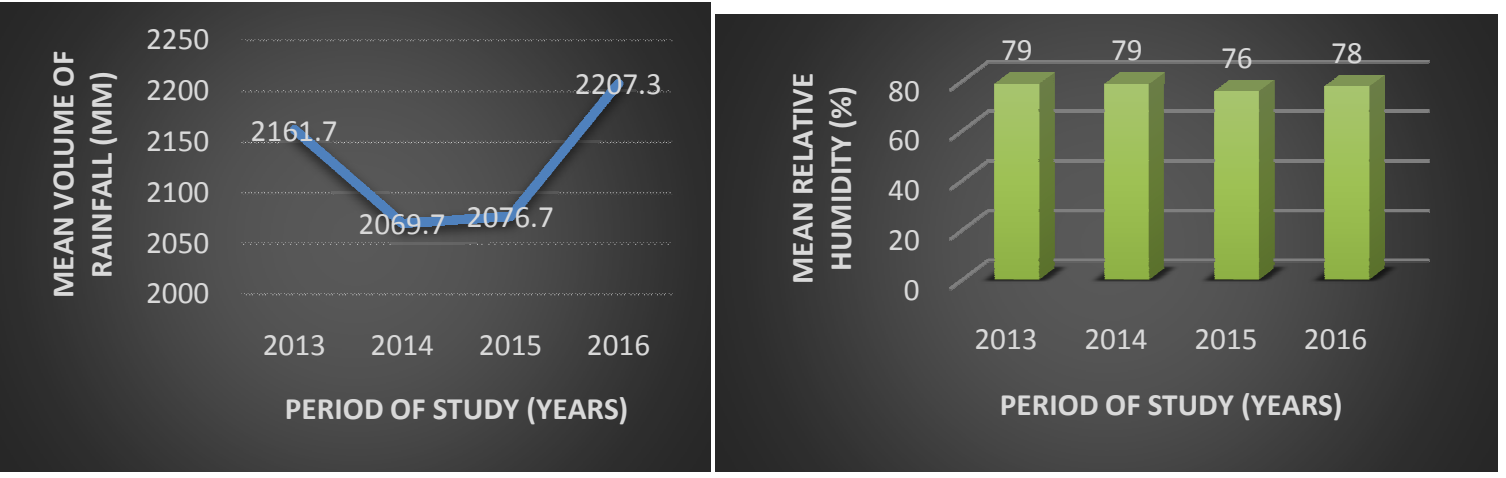

Fig. 5: Rainfall Volume

Fig.6: Relative humidity
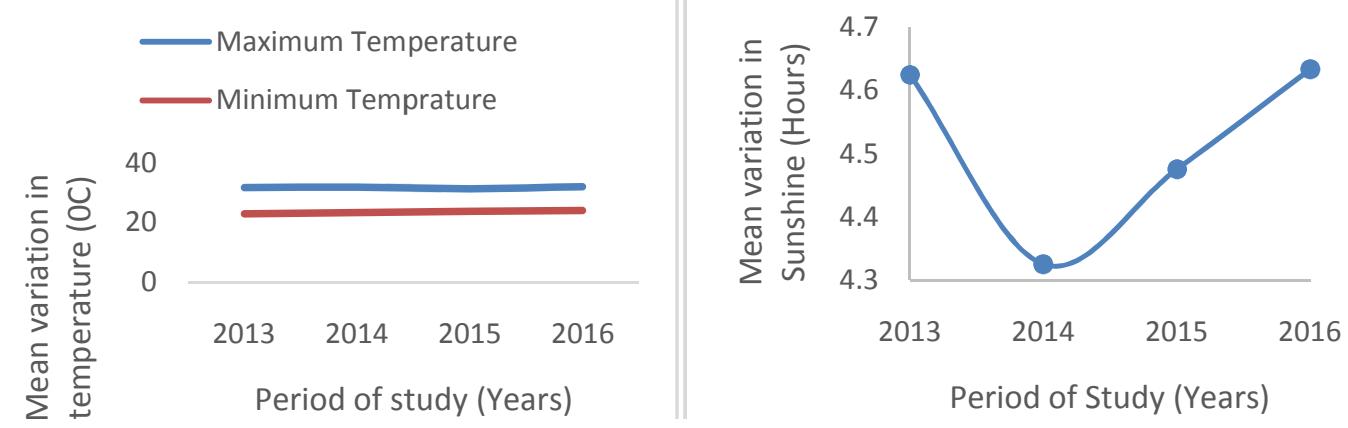

Fig. 7: Temperature variation

Fig.8: Sunshine hours 


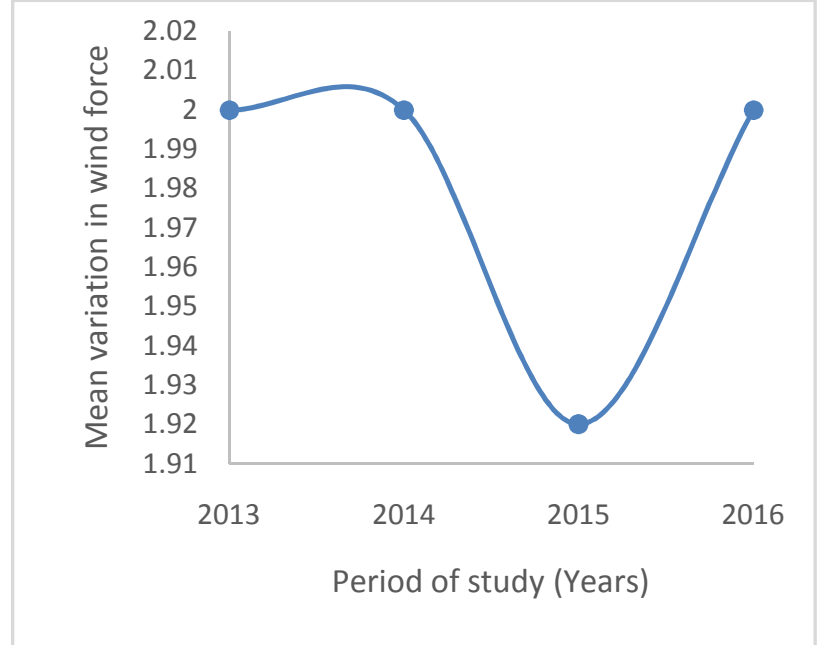

Fig. 9: Wind force Variation

Contribution of NTFPs to the livelihood outcomes of the respondents in the study area.

The distribution of the respondents to the contribution of NTFPs to their livelihood is presented (Fig. 10). The Figure showed that majorities $(91.7 \%, 77.3 \%, 89.8 \%$, $50.9 \% 61.1 \%$ and $69 \%$ ) respectively of the respondents reputed that NTFPs contributes to their household livelihood through income, jobs, food. Few proportions (45.4\%, 40.3\% and $29.6 \%)$ elucidated that NTFPs serves recreation, of medicinal roots and shrubs and fodder for their animals. NTFPs contributes so much to the food, income, shelter, job provision, relaxation, livestock nutrition and the nutrients need of the households under study. According to Nkwatoh et al., (2010) livelihood of most rural households is also dependent on NTFPs collection and trading. Trade in NTFPs played a very important role in contributing to rural household economy, thus helping the rural households to meet both their food and non-food needs. This finding is consistent with Vihotogbe, (2012); Vihotogbe et al.,(2014c) and Vihotogbe et al., (2015) who averred that NTFPs plays a vital role in rural areas and contributes to both food and non-food needs of rural households.

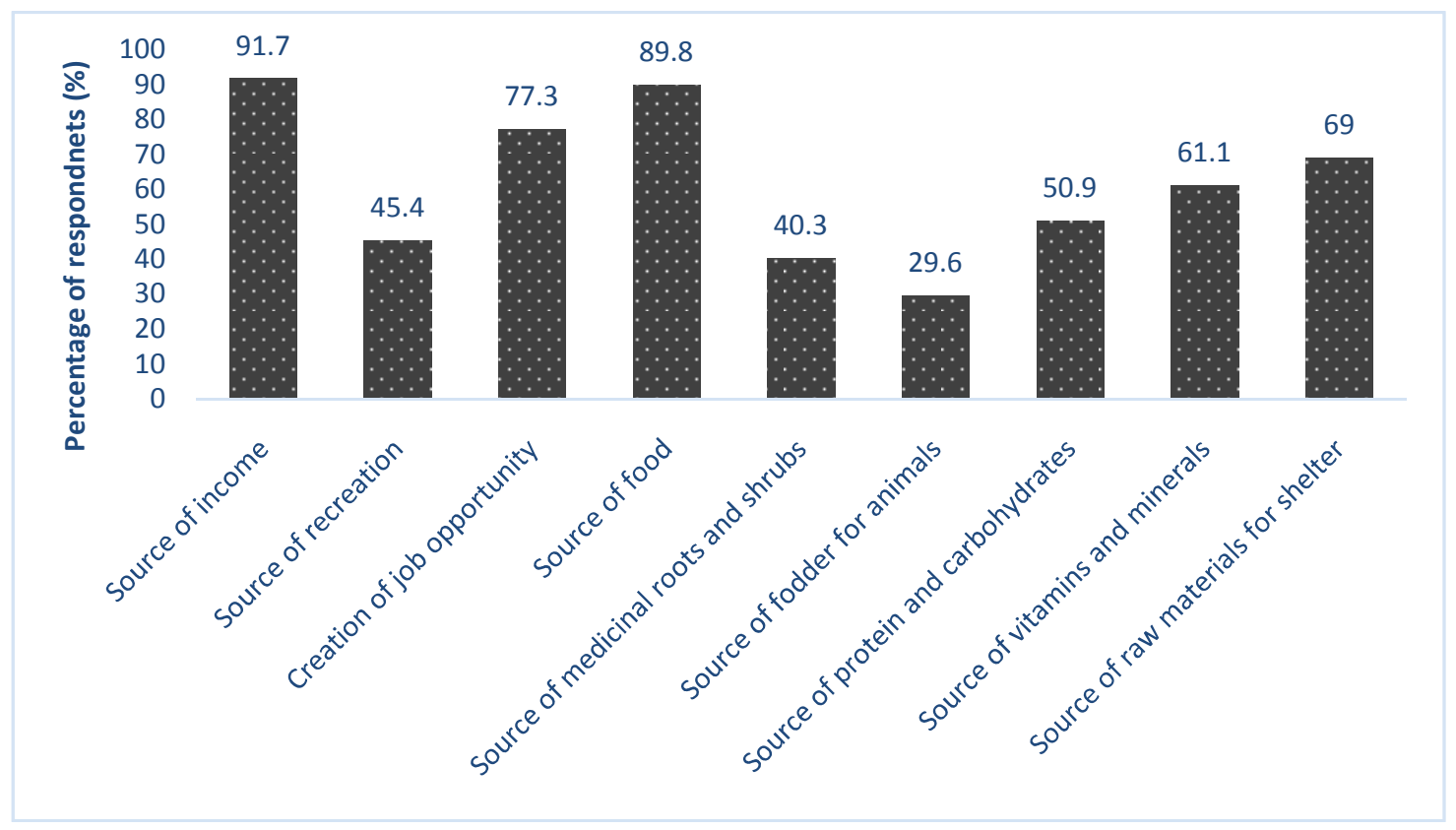

Fig.10: Contribution of NTFPs to the livelihood of the households (Multiple responses was recorded)

The total and mean amount in naira earned from NTFPs by the respondent

Results (Table 9) showed that the respondents earned highest amount from Anuofia (Bushmeat) followed by Mgborogwu (Roots) while their least earning was from
Ochiogochio (Tetrapleura Tetraptera) followed by Dennetia tripetala - Mmimmi (Pepper fruit). The cumulative amount of NTFPs harvested by all the respondents in the study area was $N 4,864,550$ with a mean value of $\mathrm{N486,455}$. The disparity between the value 
of NTFPs harvested and value of NTFPs sold by the respondents in the study area suggests that NTFPs contributes to the food and income needs of the households under study. Therefore, non-timber forest products may offer sources of income and an opportunity for poverty alleviation in rural areas under study. This finding is consistent with Mulenga et. al., (2012).
According to Mulenga et. al., (2012), households engage in trade of Non-Timber Forest Products (NTFPs) because of low capital requirements and they relatively gain easy access to markets. NTFPs help bridge seasonal gaps in income for many farmers, and they provide a safety net for many rural households during years with low crop yields.

Table 9: The total and mean amount of naira earned by the respondents from NTFPs.

\begin{tabular}{|c|c|c|c|c|c|c|c|}
\hline $\mathrm{S} / \mathrm{N}$ & $\begin{array}{l}\text { NTFPS } \\
\text { Harvested }\end{array}$ & $\begin{array}{l}\text { Unit of } \\
\text { Measurement } \\
\text { weighed in kg }\end{array}$ & $\begin{array}{l}\text { Quantity } \\
\text { Harvested }\end{array}$ & $\begin{array}{l}\text { Quantity } \\
\text { Sold }\end{array}$ & $\begin{array}{l}\text { Unit } \\
\text { price }(\mathrm{N})\end{array}$ & $\begin{array}{l}\text { Amount } \\
\text { Harvested } \\
\text { (A) }\end{array}$ & $\begin{array}{l}\text { Amount Sold } \\
\text { (N) }\end{array}$ \\
\hline 1 & $\begin{array}{l}\text { Ugbaga(Oil } \\
\text { Beans) }\end{array}$ & Bucket & $\begin{array}{l}694 \\
(5.07)\end{array}$ & $\begin{array}{l}534 \\
(3.90)\end{array}$ & 1989.05 & $\begin{array}{l}1428500 \\
(10427.01)\end{array}$ & $\begin{array}{l}1060000 \\
(7737.23)\end{array}$ \\
\hline 2 & $\begin{array}{l}\text { Uda(Guinea } \\
\text { Pepper) }\end{array}$ & Cup & $\begin{array}{l}682 \\
(7.33)\end{array}$ & $\begin{array}{l}569 \\
(6.12)\end{array}$ & 50 & $\begin{array}{l}46150 \\
(496.24)\end{array}$ & $\begin{array}{l}33700 \\
(362.37)\end{array}$ \\
\hline 3 & $\begin{array}{l}\text { Ukazi } \\
\text { (Gnetum) }\end{array}$ & Bundles & $\begin{array}{l}1358 \\
(8.43)\end{array}$ & $\begin{array}{l}1173 \\
(7.38)\end{array}$ & 502.17 & $\begin{array}{l}672750 \\
(4178.57)\end{array}$ & $\begin{array}{l}582600 \\
(3664.15)\end{array}$ \\
\hline 4 & $\begin{array}{l}\text { Ochiogochio } \\
\text { (Tetraptera) }\end{array}$ & Basins & $\begin{array}{l}278 \\
(3.52)\end{array}$ & $\begin{array}{l}249 \\
(3.15)\end{array}$ & 100 & $\begin{array}{l}27600 \\
(349.37)\end{array}$ & $\begin{array}{l}24900 \\
(315.19)\end{array}$ \\
\hline 5 & Ikolo (Snail) & Basins & $\begin{array}{l}555 \\
(5.44)\end{array}$ & $\begin{array}{l}443.5 \\
(4.39)\end{array}$ & 601.96 & $\begin{array}{l}330800 \\
(3243.14)\end{array}$ & $\begin{array}{l}265800 \\
(2631.68)\end{array}$ \\
\hline 6 & $\begin{array}{l}\text { Nmanu } \\
\text { (honey) }\end{array}$ & Bottles & $\begin{array}{l}335 \\
(5.23)\end{array}$ & $\begin{array}{l}274 \\
(4.28)\end{array}$ & 1003.13 & $\begin{array}{l}334100 \\
(5220.31)\end{array}$ & $\begin{array}{l}275560 \\
(4239.38)\end{array}$ \\
\hline 7 & $\begin{array}{l}\text { Mmimmi } \\
\text { (Pepper fruit) }\end{array}$ & Cup & $\begin{array}{l}421 \\
(7.14)\end{array}$ & $\begin{array}{l}384 \\
(6.51)\end{array}$ & 57.63 & $\begin{array}{l}22500 \\
(381.36)\end{array}$ & $\begin{array}{l}19600 \\
(332.20)\end{array}$ \\
\hline 8 & $\begin{array}{l}\text { Mgborogwu } \\
\text { (roots) }\end{array}$ & Bottles & $\begin{array}{l}355 \\
(6.45)\end{array}$ & $\begin{array}{l}296 \\
(5.38)\end{array}$ & 1990.91 & $\begin{array}{l}685000 \\
(12454.55)\end{array}$ & $\begin{array}{l}579500 \\
(10536.36)\end{array}$ \\
\hline 9 & $\begin{array}{l}\text { Anuofia } \\
\text { (Bushmeat) }\end{array}$ & None & $\begin{array}{l}196 \\
(3.02)\end{array}$ & $\begin{array}{l}140 \\
(2.15)\end{array}$ & 6046.15 & $\begin{array}{l}1181000 \\
(18169.23)\end{array}$ & $\begin{array}{l}859500 \\
(13223.08)\end{array}$ \\
\hline 10 & $\begin{array}{l}\text { Osu, Erue } \\
\text { (mushrooms) } \\
\text { Total } \\
\text { Mean }\end{array}$ & Basins & $\begin{array}{l}234.5 \\
(3.66)\end{array}$ & $\begin{array}{l}194 \\
(3.08)\end{array}$ & 577.34 & $\begin{array}{l}136150 \\
(2127.34) \\
\mathbf{4 , 8 6 4 , 5 5 0 . 0 0} \\
\mathbf{4 8 6 , 4 5 5 . 0 0}\end{array}$ & $\begin{array}{l}111400 \\
(1768.25) \\
\mathbf{3 , 8 1 2 , 5 6 0 . 0 0} \\
\mathbf{3 8 1 , 2 5 6 . 0 0}\end{array}$ \\
\hline
\end{tabular}

Note: Values in parenthesis are mean values while values outside the parenthesis are the cumulative values.

\section{CONCLUSION}

This study focused on the activities of the people that increase climate variability, the peoples' perceived effect of climate variability on the NTFPs and the contribution of NTFPs to their livelihood outcomes in Ohafia L.G.A. Abia State, Nigeria. Climate change is one of the greatest environmental, social and economic threats to the livelihood of forest dependent communities in developing countries. Effect of climate variability on NTFPs and livelihood of rural dwellers in Ohafia Local Government Area of Abia State, Nigeria has been identified in this paper. Deforestation has been excessively practiced throughout the 4 years. Changes in the amount of rain, increased intensity, and changes in rainfall patterns would weaken the root system of trees and increase the rate of wind- throw in forests, destruction and die off of many tree species that are intolerant to water logging (NEST, 2011, Abiodun et al., 2013). This will contribute to overall decline in forest cover and herbaceous understory productivity, thus affecting forest products, including NTFPs for human consumption and use. A robust finding of the study is that climate variability has an effect on NTFPs and in turn influences the livelihood of the people. Another finding of the study shows that there exists a vast indigenous and traditional knowledge of weather/climate and climate variability and change which could be tapped for sustainable adaptation to climate variability and long term climate change. To elicit this body of knowledge from the indigenous people would require more research time than the present study permits. The knowledge of the rural dwellers in the studied area however, synchronized with that of the meteorological centre at Umudike and this thus, underscores the fact that climate change is happening in the area and it is very perceptible to the rural dwellers.

\section{Recommendations however are that:}

1. The study proposed an exercise on massive domestication of NTFP in the neighboring communities and state in Nigeria as very little have been done on domestication, which makes the impact of climate variability greater and its varying impacts on the livelihood of the people

2. It is recommended that the mandates of existing weather stations be modified to include dissemination of climate information to the farmers. Community - based weather/climate information stations should be established. School-based geographical gardens should 
be established with a qualified official, preferably a school teacher with background in geography and allied subject.

3. High level of deforestation (mostly NTFPs) for fuel wood purpose, carpentry and other wood activites need to be minimized and adequate sanctions given to defaulters.

4. There should be a more insight into the wealth of vast indigenous and traditional knowledge of weather/climate and climate variability and change of the rural people which should aid in sustainable adaptation to climate variability and long term climate change.

\section{ACKNOWLEDGEMENT}

This research is supported and funded by the UK's Department for International Development (DFID) and the CLIMATE IMPACTS RESEARCH CAPACITY AND LEADERSHIP ENHANCEMENT PROGRAMME (CIRCLE) and implemented by the African Academy of Sciences and the Association of Commonwealth Universities.

\section{REFERENCES}

Abiodun, B. J., Ayobami T. S., Lawal A. K \& Abatan A. A., 2013. Potential Influence of Global Warming on Future Climate and Extreme Events in Nigeria. Regional Environmental Change.13 (3): 447-491.

Adetayo, A. O. \& Owolade E. O., 2012. Climate change and mitigation awareness in small farmers of Oyo State in Nigeria. Open Sci. Repository Agric. (open-access). e70081902.

Akponikpe, P. B. I., Johnston, P. \& Agbossou, E. K., 2010. Farmers' Perception of Climate Change and Adaptation Strategies in West-Africa. 2nd International Conference on Climate, Sustainability and Development in Semi-arid Regions, August 16-20, 2010, Brazil. pp.1-15.

Aigbe, H.I. and Oluku, S.O., 2012: Depleting Forest Resources of Nigeria and its Impact on Climate. Journal of Agricultural and Social Resources (JASR). Vol. 12 No. 2, 2012

Bernard, H. R., 2005. Research Methods in Anthropology: Qualitative and Quantitative Approaches. Lanham: Altamira Press.

Chidumayo, E., 2011. Climate change and the woodlands of Africa. In: Climate Change and African Forest and Wildlife Resources. (Edited by Chidumayo, E., et al.), African Forest Forum, Nairobi, Kenya. pp. $85-101$.

Ibe, G. O., Ezenwa, L. I., Uwaga, M. A.and Ngwuli, C.P., 2018. Assessment of challenges faced by nontimber forest products (NTFPS) dependents'communities in a changing climate: $A$ case of adaptation measures in Ohafia LGA, Abia State, Nigeria. Journal of Research in Forestry, Wildlife \& Environment Vol. 10 (2) June, 2018 pp $39-46$.
Ikehi, M. E., 2014. Impacts of climate change on animal and crop production in Niger Delta Region of Nigeria. Res. J. Agric. Environ. Management. 3(10):528-537.

Ikehi, M. E, Ifeanyieze, F.O., Ugwuoke, C.U., 2014a. Integration of climate change into the senior secondary school Agricultural Science curriculum in Nigeria. Journal of Atmospheric and Climate Sciences. 4:614-621.

Ikojo, H.A, Udofia, S.I and Azeez, A., 2003: Community forestry approach to poverty alleviation in rural areas. In: Akindele, S.O. and Popoola, L. (eds), proceedings of the 29th Annual Conference of the Forestry Association of Nigeria (FAN) held in Calabar between 6th-11th October, 2003 Pp1-8.

Jimoh, S.O. and Adebisi, S.R., 2005: Non-timber forest products and sustainable Forest management in Nigeria. In: Popoola, L, Mfon, P. and Oni, P.I. (eds). Proceedings of the 30th Annual conference of FAN held in Kaduna, Kaduna state, Nigeria. Between 7th and 11th November, 2005. Pp 266271

Maeda, E. E., Pellikka, P.K.E., Clark, B.J.F., \& Siljander, M., 2011. Potential impacts of agricultural expansion and climate change on soil erosion in the Eastern Arc Mountains of Kenya. Geomorphology. 123(3), 279-289.

Msalilwa, U., , S. \& Gillah, P.R., 2013. Community perception on climate change and useage patterns of Non-Timber Forest Products by communities around Kilolo Districts, Tanzania Ethiopian Journal of Environmental Studies and Management. 6 (5): 507-516

Mulenga, B. P., Richardson, R. B. \& Tembo, G., 2012. Non-Timber Forest Products and Rural Poverty Alleviation in Zambia. Indaba Agricultural Policy Research Institute (IAPRI) Lusaka, Zambia. Pg. 12.

NRCRI National Root Crop Research Institute Umudike Meteorological and Soil Divisions, Unpublished reports of the Abia State. (2004 and 2005).

Nigerian Environmental Study Action Team (NEST). (2011). National Adaptation Strategy and Plan of Action on Climate Change for Nigeria (NASPACNN). Building Nigeria Responses to Climate Change (BNRCC) project. Available at www.nestinteractive.org (assessed 8 May, 2012). pp.1-78.

Nkwatoh, A. F., Popoola, L., lyassa, S. M. \& Nkwatoh, F. W., 2010. Evaluation of Irvingia (I. gabonensis and I. wombulu .Bali).Trade; A Major Non-Timber Forest Product in the Ejagham Forest Reserve of Southwest Cameroon. Ethiopian Journal of 
Environmental Studies and Management. 3(1):7077.

Odebode, SO. Preparing a research report. In Oladele, IO Akinbeli, LA and Adekoya, AE (eds.)Social Science Research Approaches Techniques and Reporting, ljebu-Ode Shanu Books Ltd. 1999; Pp 77-87.

Udeagha, A. U., 2014. Impacts of climate change on the contributions of selected Non-Timber Forest Products (NTFPS) to rural household economy in Cross River State, Nigeria. M.Sc dissertation submitted to the Department of Forestry and Wildlife, University of Uyo, Uyo, Akwa Ibom State, Nigeria.

Umoh, G. S \& Eketekpe, F., 2010. Climate change and agriculture in the Niger Delta: A study of wetlands Farmers. Adaptation to climate variability in Bayelsa State. In: Nmadu JN, Ojo MA, Mohamed US, Baba KM, Ibraham FD and Yisa ES (eds). Commercial Agriculture, Banking Reform and Economic Down turn. Setting a new Agenda for
Agricultural development in Nigeria. Proceeding of 11th Annual National Conference of National Association of Agricultural Economist Association.

Vihotogbe, R. Van den Berg, R. G., Missihoun, A. A., Sinsin, B. \& Sosef, M. S. (2015). Genetic diversity of bitter and sweet African bush mango trees (Irvingia spp.,Irvingiaceae) in West and Central Africa. African Journal of Biotechnology. 14(45):3062-3074.

Vihotogbe, R., 2012. Characterization of African Bush Mango Tree (ABMT) with Emphasis on the Differences between Sweet and Bitter Trees in the Dahomey Gap (West Africa), Unpublished Ph.D Thesis, Wageningen University, Wageningen. pp.1-189.

Vihotogbe, R. Houessou, L. G., Assogbadjo, A. E \& Sinsin, B., 2014c. Germination of Seeds from earlier Fruits of Bitter and Sweet African Bush Mango Trees. African Crop Science Journal. 22(4): 291-301. 